\section{A Tribute to Michael Moles}

\section{Steven J. Rottman, MD, FACEP} President, World Association for Disaster and Emergency
Medicine (WADEM)

He who saves one life is as one who bas saved a whole world.

These are the words of the early Rabbis written in the Talmud, as they interpreted the text of the Torah, the Hebrew Bible.

One life touches the lives of so many others... a world of people from so many different walks of life and backgrounds. And in turn, the lives of each one of those people touch others, and perhaps bring some magical spark of the influence of that first person into the ever brighter flame of humanity. So you see, to save one life, then, does, indeed, save a whole "world".

Michael Moles saved many lives during his years of clinical practice, refugee work, and through the giving of his skills and knowledge by teaching so many others the art and science of our noble profession. The amplification of Mike's impact through his students and peers truly reflects the intent of those ancient Talmudic words; he has saved many worlds.

I wonder, then, can the converse also be true? Does not an entire world feel the impact of the loss of one life? In the case of Michael Moles, I believe this to be the case. Those with immediate, day-to-day contact with Mike undoubtedly felt and continue to feel the fracture coursing through their "worlds" since his death.

And on the more tangible global scale, I can tell you that I have received communications from colleagues around the world, all expressing their admiration and respect for this giant among us in the emergency and disaster medical field.

Let me capture some of this impact for you, as reflected by our international colleagues in their own words:

Jakov Adler, Israel:

We have lost a great bumanitarian who advocated peace and the improvement of health and welfare of all underprivileged populations in the world. Moreover, he was one of the few who went into the field to implement bis ideas in providing bealth care to those who needed it most. We will all be poorer after losing this warm and wonderful person!

Knut Ole Sundnes, Norway:

This is a hard blow. I came to appreciate Mike, and I counted on bim as a friend, as well as a key person to help to elevate WADEM to a new level in the world of Disaster and
Emergency Medicine. We must make bis dreams become reality. Mike deserves that.

Ronald Stewart, Canada:

[To Pat] Words are poor vessels to carry the full weight of our feelings and to convey our concern and distress at your loss, but be assured we loved and treasured bis friendship, his wit, bis love of life, and his dedication and bumanity.

[To all] I grieve with you all, but raise my voice with you in gratitude for bis life that so wonderfully touched those be metand we are so much the better for that touching.

Ahmed Ammar, Egypt:

Michael was a very good friend, with great vision and extraordinary abilities to give-To give from bis heart, time, and mind.

Frank Archer, Australia:

It is indeed sad to bear of the passing of Mike Moles. As one of my colleagues, a British trained Melbourne Anaesthetist said yesterday, "I feel a bit lost". We... have benefited from his wisdom as we were preparing for the Melbourne Congress. No doubt, Lyon will provide a forum to pay proper tribute to a man who has indeed bad a global influence.

Jean Marie Fonrouge, France:

Mike had full passion, courage, and humanism. I have a lot sadness because he was an bonest man, respectful and collegiate. Mike will be among us in Lyon. This Congress will be bis... "bis" Congress.

Leonid M. Roshal, Russia:

We have lost a wonderful man. His death was untimely. I am proud of our friendship. He was a person who belongs to the world, be fully gave bimself to people, and we never shall forget bim.

And now, my own reflections...

I've been thinking about Mike virtually every day since Judith phoned me that sad Thursday morning, and have found myself smiling quietly to myself most of the time, actually laughing out loud at others, all punctuated with occasional tears.

As I wrote in a note to Peter Baskett, Mike, along with Peter, were my mentors; something like the big brothers opening the door to the international emergency and disaster medicine community for the younger adolescent, corrupting me as much as $I$ could stand along the way with good fellowship, stories, scholarly work, and international adventures.

Mike was working so hard for all of us at WADEM, to infuse the types of changes our organization has long needed. His long-time efforts to synthesize the collaborative relationship of the international disaster medical societies under a single umbrella will become realized in Lyon.

Mike had a marvelous way with language, a fantastic wit, a great respect for matters of protocol, and an unparalleled sense of humor. His death is a stunning blow to all of us; we have lost a great friend and colleague. 
Let us all make every effort to enact his programs as part of a sustaining memorial to his commitment to humanitarian medicine, not only through our own individual efforts, but through those of WADEM and through the inclusion of the rest of our physical world, through the Michael Moles Memorial Fellowship, endowing membership support for physicians, nurses, and paramedical personnel from those regions of the globe in which the economic circumstances would otherwise prohibit their participation in our Association.

I invite you to raise your glasses in a memorial tribute to our good friend and, as Leonid Roshal so simply and beautifully put it, a man who "belonged to the world."

\section{Michael:}

\section{A Reminiscence}

\section{Malcolm Fisher}

A few years ago I was sitting in a bar in Ecuador with Phil. And Phil said to me that one of the best things in medicine was the people you meet. I concurred.

I like charisma in a doctor. Both conservative charisma and larrikin charisma. The last charismatic doctor I spent time with was a retired U.S. burns surgeon. He had a frightening familiarity with the literature matched by his experience and teaching skills. He argued with a twinkle in his eye. I came away smarter and feeling good. There is a charisma shortage in medicine today.

The charismatic doctors I have met are mostly dead, and don't appear replaceable. Where is today's Fred Hollowes?

I cannot remember how many years ago I met Michael. It was in a bar in Hong Kong. I had been taken there to meet him. We drank together. Scotch Whisky. At two o'clock in the morning, he said to me, "You know, I am going to like you, and that is unfortunate because I can tell that you are trouble."

The next night, we wound up in Peter's room with two bottles of Scotch. They were raconteurs of incredible talent. I kept notes on their stories to use in my column, but sadly only one story was legible.

It was the tale of when Michael was in the Guard of Honour for the Queen's visit to Hong Kong. He wore his Sam Browne on the wrong diagonal. After the show was over, he waited in the Officer's mess until he received the summon to the Seargeant's mess where a gleaming RSM sat in solitude.

"Saar," said the RSM. "Today you committed a serious breach of dress regulations in the presence of her Majesty."

"Guilty," replied Michael.

"Saar, it is my understanding that in this situation the officer concerned is to shout the mess of the soldier who brings the breach to his attention, Saar."

"That would seem suitable under the circumstances, Sar-Major," replied Michael.

"Saar, it is also traditional that I should choose the drink, under the circumstances, Saar."

"That would certainly be in order, Sar-Major."

"Very well, saar. Tonight we shall be drinking Drambuie Shandy, Saar."

Michael was encouraged, as he felt sure he could manage a single RSM. " Two Drambuie shandys, please barman."

"One moment sir," said the RSM, and then bellowed, as only a British RSM can, "Squaad."

Through the door marched every Seargeant in Hong Kong. It cost Michael three months pay.

Michael used to turn up. Gaunt and Safari-suited. It was always great to hear his new story. He specialised in those very long and subtle jokes that only the Pommiest of 